\title{
ASEAN-led Multilateralism and Regional Order: The Great Power Bargain Deficit
}

Evelyn Goh, Strategic and Defence Studies Centre of the Australian National University

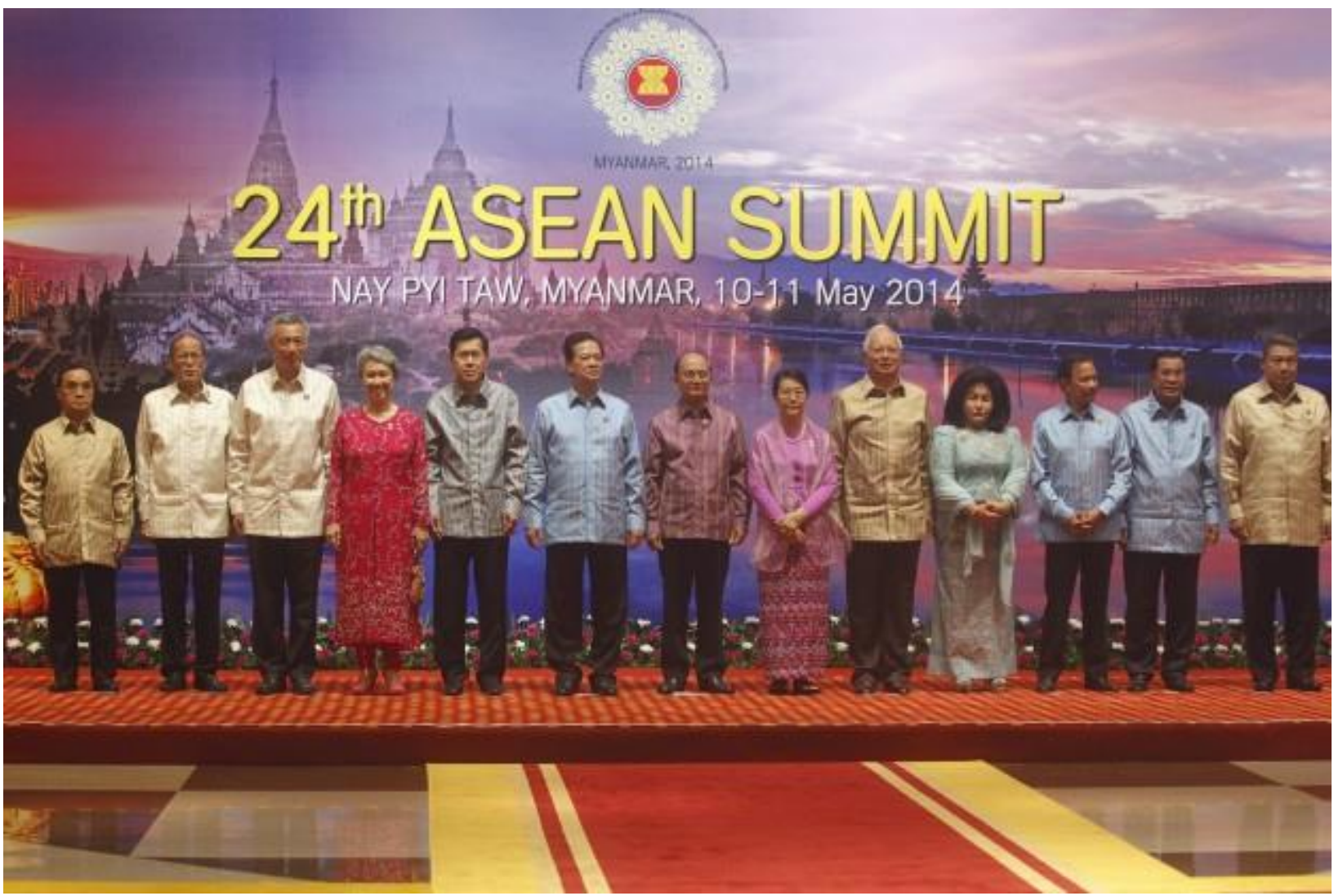

Soe Zeya CREUTERS

The post-Cold War East Asian and Asia-Pacific strategic landscape has been dominated by three factors: 1) the United States' military preponderance underpinned by its hub-and-spokes San Francisco system of bilateral alliances; 2) China's seemingly inexorable resurgence economically as well as diplomatically and militarily; and 3) the proliferation of multilateral regional dialogues, initiatives, and institutions, many with the region's oldest multilateral grouping - the ten-member ASEAN—at their heart. For the 
majority of scholars and policymakers who work from a de facto realist standpoint and are unsurprised by the determining effects of great powers, alliances, and relative power distribution on regional stability, the seemingly disproportionate impact of the smaller ASEAN states has drawn attention and contention. Do these strategically less significant Southeast Asian states "punch above their weight" in regional affairs because of their unique ability to create new multilateral institutions for security and economic cooperation, or is their rhetoric about the merits of multilateralism and transformative potential of regional institutions and regionalism "cheap" talk and deluded ambition?

In recent years, key developments within ASEAN and East Asia indeed suggest good reasons to re-evaluate the extent to which ASEAN-led multilateralism has contributed to regional order. For instance, there has been growing competitive regionalism in both the trade and security arenas in which regional institutions seem to have become instruments and extensions of great power competition. At the same time, regional conflict hotspots remain active; in particular, the last five years have witnessed intensifying tensions and security dilemmas in the maritime zones, fuelled by perceived Chinese re-assertiveness against Japan, the United States, and some Southeast Asian states. Notably, ASEAN has had increasing difficulties with holding a common stance vis-a-vis maritime territorial conflicts with China. Against this background, the United States has reinvigorated its security presence in East Asia, using its traditional bilateral alliances and new bilateral defence partnerships. These developments suggest that regional subscription to ASEAN-led multilateralism may be more instrumental and less effective in mediating key conflicts of interest than expected, and that regional security and stability are still primarily determined by great power politics. 
In what follows, I examine ASEAN's contributions to regional order, paying particular attention to the multilateral institutions the association leads and the expectations about multilateralism's transformative potential that they have stimulated. The analysis is organized in three parts, beginning with a discussion of the relationship between multilateralism, regional institutions, and regional order. This is followed by an evaluation of the major achievements and contributions of ASEAN-led institutions to creating East Asia's post-Cold War order, while the last section highlights the key limitations in ASEAN endeavors to build a sustainable regional order. I advance two main propositions: first, that ASEAN's vital contribution to regional order was in persuading the great powers to commit to a supplementary supporting structure of multilateral confidence-building at a critical juncture of strategic transition after the Cold War ended. Second, however, ASEAN's mode of multilateralism has grown less effective as the regional strategic challenges have evolved over the last two decades. Increasingly, ASEAN's approach to enmeshing the great powers in regional multilateral institutions may be outdated, as it cannot help to bring about the negotiation of modus vivendi among the great powers themselves so necessary to managing regional stability over the medium- to long-term.

\section{Multilateralism, ASEAN-led Institutions, and Regional Order}

Since the end of the Cold War, the international system has been marked by uncertainties about triumphant unipolarity, the rapid rise of new great powers, and unprecedented global interdependence. The imperative at both the global and regional levels has been to create a new, stable international order. The notion of "order" tends to be conflated with peace or the absence of war; however, the classical understanding of international order refers to the condition of sustained, rule-governed interaction among states that share common understandings about their primary goals and means of conducting international affairs. $\stackrel{\perp}{ }$ From this perspective, the maintenance of international 
order must involve limits on behavior, management of conflict, and accommodation of change without undermining the common goals and values of this international society-i.e., achieving international order is about agreeing on (and eventually institutionalizing) limits to power and competition, rather than about obliterating conflict per se. 2 Conceiving of order as norm-governed interaction strongly reinforces the vital role of sustained cooperation in international life. In this regard, as liberals would assert, commitments to multilateralism and effective multilateral institutions are core normative and functional elements of order.

Multilateralism and related institutions can also be vital means of managing power politics, especially the effects of unequal power. For instance, while the ascent of China represents a significant redistribution of power in the contemporary international system, the issue is not simply or even primarily the need to balance its rising power with similar opposing capabilities. Rather, the main challenge is how to harness China and other powers to some collective authority, or to embed them within stable structures of interstate cooperation - not just to prevent war between them, but more to protect the orderly functioning of international life along agreed rules and norms. ${ }^{3}$ With this understanding, multilateral cooperation and institutions take on a much more important role in the management of unequal power in the international system. Even from a stark rational-choice perspective, multilateral cooperation is important as both an instrument of domination by great powers and a means for smaller states to constrain hegemony. For the powerful state, multilateral cooperation lowers transaction costs, especially in instances of standardization; and helps to deflect potential challenges from weaker states by ceding some degree of decision-making and thus lowering policing and enforcement costs. ${ }^{ \pm}$Leading states require cooperative mechanisms with other states to provide public goods, such as free trade or security. Normatively, the costs of hegemony can also be reduced if the hegemon 
supplements and sustains its material dominance by constructing a social framework that legitimizes its power and leadership. Cooperative multilateral institutions are a key form of such frameworks through which a hegemonic power agrees to bind itself to specified voluntary strategic restraints in dealing with its weaker partners, in return for the latter's long-term, institutionalized cooperation. ${ }^{5}$ Weaker states in turn gain limits on the action of the leading state and access to political process in which they can press their interests. Thus, multilateral cooperation and institutions help to legitimize as well as tame unequal power: first, they institutionalize or perpetuate in a sustained manner the structural domination of great powers; second, they also bind all members, but especially the stronger states, using rules and other normative expectations of conduct. Over the long term, multilateral institutions are also important sites of codified norms for governance which can provide building blocks for identity- and value-based "security communities" within which the use of force is inconceivable.

Multilateralism is not necessarily order-building in and of itself: it is a channel of action, the results of which depend on substantive and normative agreement that may or may not be achieved. This distinction is fudged in the Asia-Pacific security lexicon, within which "multilateralism" is something of an onion. Generically, the term ought to refer to coordinated modes of action that involve multiple numbers of participants. Peeling away the layers in regional usage, however, reveals the assumption of active cooperation, not just coordination; and the conflation of the concept with regional organisations or cooperative regimes or fully-fledged institutions. This is usually accompanied by the implicit or explicit value judgment that "multilateralism is good, bilateralism is bad." With the drive towards various versions of East Asian "community" gathering pace in the 2000s, many analysts also began to use "multilateralism" interchangeably with "regionalism"- a frustrating confusion between channels of action on the one 
hand, and normative ambitions about collective identity and capacity on the other.

These expansive and normative understandings of multilateralism arise from Asia-Pacific discourse in the immediate aftermath of the Cold War, which sought to draw from the European notion of seeking "security with" postcommunist partner states within a regional framework, rather than deterrence or balance of power-based strategies for achieving "security against" enemies. While a number of other states and actors-including the Canadians, Australians, and Japanese-actively drove these early debates, ASEAN captured the eventual regional multilateral institution-building process and grounded it specifically in "cooperative security" conceptions, stressing the development of a multilateral "habit of dialogue," cooperation and compromise in an evolutionary, pragmatic, informal, consultative and consensual manner. ${ }^{6}$ Encapsulated in the ASEAN Regional Forum (ARF), ASEAN-led multilateralism would be characterized by three features: leadership by weaker states, soft institutionalization (i.e. the avoidance of formal or binding approaches to problem-solving and collective action), and inclusiveness. ${ }^{?}$ As the next section details, ASEAN's approach has helped to create a post-Cold War regional order that is distinctive for the way in which multilateral institutions have largely managed to coexist with and not supplant either traditional security arrangements (such as alliances) or narrower bilateral or wider global structures of economic governance. However, I go on to argue that part of ASEAN's success is that the multilateral channels of cooperation within regional institutions and the normative desirability of multilateralism alongside regionalism have become the ends in themselves, rather than the means to achieving a stable and sustainable regional order.

\section{ASEAN's Achievements in Regional Multilateralism}




\section{Adaptation and innovation}

The establishment of the ARF in 1994 represented the triumph of ASEANstyle multilateralism in the wider Asia-Pacific. It also remains the prime example of the Southeast Asian states' ability to adapt to new strategic circumstances and to formulate new concepts acceptable to other regional players that could underpin multilateral security and economic cooperation. It is important to acknowledge that the ARF did not entail the simple scaling-up or extrapolation of pre-existing ASEAN norms. As Alice Ba has shown in detail,, in negotiating the ARF, ASEAN states had to make relatively radical departures from their original, hard-won norms against intra-regional military or security consultations, and against extra-regional multilateral security relations, both of which were seen as violating the association's founding principles of non-interference and regional autonomy. ASEAN adapted to post-Cold War imperatives by conceding these objections, but in return insisted on maintaining leadership and using its own political priorities and diplomatic process to shape the nature of the ARF. Thus ARF members endorsed ASEAN's Treaty of Amity and Cooperation (TAC) as a "code of conduct," and adopted ASEAN's version of "cooperative security." The latter emphasized inclusivity and informality, which implied equality and prevented agenda-hogging by the Western states; a loose dialogue format and non-intrusive voluntary-compliance processes, which assuaged Asian concerns about potentially legalistic negotiations over sensitive issues such as arms control and internal affairs such as human rights, democratization, and territorial claims; and complementarity with existing US alliances. ${ }^{2}$ Further, the innovation of being led by small states that had a "counterrealpolitik" agenda would preclude domination by any one great power. 10 Of particular note here is the way in which Southeast Asian concerns about nontraditional, trans-boundary, and non-military security issues-including infectious diseases, piracy, trafficking, money laundering, and terrorism- 
have come to form the core of regional security cooperation in the ARF and other ASEAN-led regional institutions. $\stackrel{11}{ }$ Such widening of the concept of security provides for less strategically demanding cooperation through functional collaboration, while leaving unchallenged the military alliances and grand strategic consultations and coordination traditionally associated with great powers.

\section{Inclusivity}

Arguably, ASEAN's greatest achievement vis-à-vis Asian multilateralism has been to promote, assert, and protect the basic principle of inclusivity in regional institutions. From the start, ASEAN's ability to bring together all the relevant great powers in the ARF was no mean feat considering the initial opposition or reservations in Washington, Beijing, and Tokyo, especially concerning an inclusive regional security dialogue. The above characteristics of ASEAN-led cooperative security helped to assuage these three key powers' worries about being unduly constrained by multilateral institutions. But ASEAN also went on to help establish an extensive definition of the Asia-Pacific region, by reinforcing the immutable US role in East Asia, by attaching South Asia (via India and Pakistan) as well as Australia and New Zealand, and by extending Russia's membership in various regional frameworks, including the East Asia Summit (EAS). The importance of such inclusiveness to the regional architecture was twofold: first, it helped to legitimize the security interests and role of each of these great powers in East Asia; and second, it also institutionalized the small states' and middle powers' claims to legitimate voice and political relevance in the management of regional security affairs. 
ASEAN-led multilateralism was particularly important in helping to justify the preponderant US presence in East Asia beyond the Cold War. In the immediate post-Cold War years, the George H. W. Bush administration retracted its initial objection to the proposals for a multilateral security institution because it was useful as part of a strategy to signal that the United States remained committed to its central security role in the Asia-Pacific in spite of its planned military reductions. When the Clinton administration began to update its regional alliances, participating in the ARF provided a way to supplement its bilateral alliances and forward military presence. 12 During this period, many ASEAN states retained a strong belief in the US role as a regional security guarantor, $\underline{13}$ and when faced with the acute uncertainty about continued US security commitments, their reaction was to reinforce their security binding with the United States using a variety of bilateral security partnerships, but also multilateral institutions. For many ASEAN states, the choice of a wide, inclusive "Asia-Pacific" membershiprather than a more geographically limited "East Asia" one-centered on the need to "keep the US in." The ARF crucially helped to lend legitimacy to ASEAN's desire for an integral US role in regional security. As Singapore Prime Minister Goh Chok Tong put it: through the ARF, ASEAN had "changed the political context of US engagement" because these countries had "exercised their sovereign prerogative to invite the US to join them in discussing the affairs of Southeast Asia." As a result, "no one can argue that the US presence in Southeast Asia is illegitimate or an intrusion into the region." 14

Japan shared this aim of using inclusive multilateral institutions to legitimize Washington's security guarantee under different circumstances. For other regional states too, these secondary security and economic institutions would help to justify why Japan would not need to seek a radical independent strategic role after the Cold War. Instead, the security-related multilateral 
institutions in particular would support the US-Japan alliance by providing a forum to discuss Asian fears about Japanese security strategy and to allow Japan to reassure its neighbors about its expanded burden-sharing within the alliance. $\frac{15}{2}$

In contrast, a particular effort was not required to justify China's entitlement as a rising regional great power to a special role in East Asian security. Instead, the ASEAN-led multilateral institutions helped to give China what it urgently needed in terms of legitimacy and social status in international society. Against this background, ASEAN's second major rationale for creating the ARF was to provide a multilateral normative setting to "socialize" China into being a status quo power. Unappealing as this was to Beijing, it initially joined to avoid isolation. ${ }^{16}$ From the mid-1990s, Chinese leaders and officials began to appreciate the value of the ARF and other multilateral institutions for legitimizing China's rising power. 17 By subscribing to key ASEAN norms and practices-especially sovereignty, non-interference, the non-use of force, and non-traditional security cooperation-China used these regional institutions as premier demonstration precincts to showcase its new sociability and to reassure neighbors about its benign intentions and commitment to a "peaceful rise" and regional stability. 18

Insofar as a large measure of the logic of ASEAN-style multilateral institutions relies on the constructivist conviction that institutional membership would, over the medium term, create expectations and obligations on the part of the great powers, and over time, socialize them into embracing peaceful norms, China's voluntary self-restraint and pursuit of mutual benefits signalled a good start to what was potentially the most dangerous part of the post-Cold War transition. Hence, China's compliance with the ARF norm of issuing defense white papers; its hosting of 
multilateral working groups and meetings; its introduction of a "new security concept" stressing peaceful coexistence and cooperative security; its initiative for a China-ASEAN free trade area; and its participation in the multilateral negotiations of the South China Sea territorial disputes with ASEAN leading to the 2002 Declaration of Conduct all suggested that China was responding to being socially and morally bound to some degree to peaceful modes of interaction. 19 As China's power has grown over the last two decades, Beijing's willingness to stake at least a part of its regional legitimacy as a great power on its relationship with ASEAN has also increased the pressure on other great powers to affirm the centrality of ASEAN and its multilateral norms. For instance, the Obama administration was persuaded to sign up to ASEAN's TAC in 2010 in order to be included in the EAS alongside China, Japan, and Russia among others.

\section{Institutionalizing small state voices}

That ASEAN has over the last two decades developed its bilateral "ASEAN+" dialogues with each great power, and created additional ASEAN centred regional institutions-ASEAN+3, the EAS, and the ASEAN Defense Ministers Meeting Plus, 20 - testifies to what Eaton and Stubbs called its "competence power," 21 its ability cohesively and normatively to shape and frame regional perceptions and approaches to security cooperation in ways beneficial to itself. This is manifested in the logistics, functions, and norms of the resulting institutions, which meet in Southeast Asia in conjunction with ASEAN's own summit, have their agendas set by the ASEAN Chair, and - in the case of the EAS - have their criteria of membership determined by accession to TAC, formal recognition as an ASEAN "dialogue partner," and unanimous acceptance by ASEAN. This driver's seat grants ASEAN structural power because these large regional institutions are difficult to "reprogram": subsequent regionalist developments must adapt to, or be 
grafted onto, these ASEAN-led institutions already entrenched at the heart of the strategic architecture. $\underline{22}$

\section{Limitations of ASEAN-led Institutions in Creating Regional Order}

Nearly 25 years into the post-Cold War adjustment process, we are in a position now to recognize the peculiar context of ASEAN's achievements in promulgating wider Asian multilateralism, which was marked by the acute and widespread uncertainties of order transition. This milieu created unique space for ASEAN states and supporters to persuade others that multilateral institutions could critically help in "defusing the conflictual by-products of power balancing practices" while they tried to forge new world and regional orders. ${ }^{23}$ As this process advanced, however, the assumed benefits and cumulative effects of ASEAN-style multilateralism became increasingly questionable for four main reasons.

\section{Restricted scope and domain}

First, the issue scope and oversight domain of these ASEAN-centered regional institutions have remained limited. Judging its transformative potential is difficult because many of the key "hard" cases of regional security conflicts are not dealt with through these institutions, and member states do not treat these institutions as channels of first resort in preventing or resolving conflicts, but instead rely on bilateral and other avenues. ${ }^{24}$ The ASEAN style of multilateral institutionalism brought the United States, China, and other major powers to the table precisely because the informal, consensual, and non-binding norms entailed were relatively non-demanding, low cost, and low stakes. ${ }^{25}$ In spite of their rhetorical ascription to TAC, the informal character of the security institutions in particular assured the United States and China that they would not have to be bound by formal agreements; consensual decision-making procedures meant that they could prevent 
discussion or action on issues against their interest; and the lack of any enforcement mechanism essentially left them with a free hand to pursue unilateral policies when necessary. For instance, Beijing has not felt itself constrained by ARF or EAS norms in maritime confrontations with the Philippines, Vietnam, and the United States in the South China Sea.

\section{Minimalist norms}

Second, having lured the various great power and other stakeholders to the table with these non-demanding and non-intrusive norms, ASEAN has subsequently provided conservatives with a minimalist normative position from which to resist others' attempts to negotiate new strategic norms or rules of regional behaviour. One of the major reasons for the resilience of the "ASEAN Way" in East Asian institutionalism is that ASEAN has found a major normative ally in Beijing: China has successfully utilized it to block the development of other norms that would entail more sustained restraint, transparency, and scrutiny. ${ }^{26}$ China has lent its considerable weight to the more conservative Southeast Asian states' wariness about the in troduction of potentially intrusive norms, and has successfully hampered progress toward preventive diplomacy and conflict resolution in the ARF, against the efforts of the United States, Australia, and Canada. Beijing also further entrenched ASEAN's non-intervention principle by ruling out any discussion within regional institutions of Taiwan and what it regarded as domestic Chinese security affairs, such as Tibet and Xinjiang. China has also leveraged ASEAN's conflict avoidance norm to resist addressing the South China Sea disputes within these multilateral institutions. ASEAN's style generated the non-binding 2002 Declaration of Conduct, which was loose enough to allow China to continue to pursue bilateral actions such as the controversial joint exploration agreement with the Philippines in 2004, and to oppose over the next decade ASEAN's attempts to negotiate multilaterally on the Code of 
Conduct. At the 2012 ASEAN summit, Beijing successfully exploited ASEAN's consensus principle to put pressure on Cambodia as chair not to issue the traditional ASEAN joint statement because the draft included a negative reference to China's confrontation with the Philippines over a disputed shoal in the South China Sea.

\section{Institution-racing}

Third, ASEAN's model of "comfortable" regionalism allows the great powers in collusion with smaller states to treat regional institutions as instruments of so-called "soft" balancing, more than as sites for institutionalizing regional "rules of the game" that would contribute to a sustainable modus vivendi among the great powers. This tends to channel great power balancing behavior into a stagnant pool of non-military, but still deeply political and ultimately non-productive, blocking manoeuvres. These dynamics surfaced most clearly after the 1997 financial crisis, when ASEAN once again demonstrated its unique ability to marshal multilateralism using its "ASEA +" mechanisms. In establishing the ASEAN+3 framework for regional economic and financial cooperation in 1997, ASEAN created the first exclusive East Asian institution in which China and Japan would have to share leadership. This expressed a consensus on "East Asia" as a regional community and legitimized the pursuit of regional institutions excluding the United States. 27 However, this consensus broke down over the next five years because of renewed uncertainties about US security commitments after the terrorist attacks of September 2001 and deteriorating Sino-Japanese relations. Subsequently, power competition and balancing by Japan and China within and across regional institutions intensified in a round of "institutionracing." 28 
Hence, the widely-publicized disagreements about membership in the EAS in 2005, which saw China_with Malaysian support—pushing for intensifying and broadening the scope of cooperation within the exclusive ASEAN +3 community, against opposition from Japan-along with Indonesia and Singapore-, which successfully lobbied for the inclusion of Australia, India, and New Zealand, in order to stave off potential Chinese domination within the EAS. The current coexistence of the EAS alongside the ARF provides two regional groupings with overlapping mandates for cooperation in finance, energy, education, and disease and natural disaster management.

Competing initiatives for regional integration similarly dog the economic landscape. After Beijing surprisingly proposed a China-ASEAN FTA in 2000, Tokyo quickly followed up with a suggestion for a Japan-ASEAN FTA; they then took this battle to the wider East Asian region with China putting its weight behind the idea of an exclusive ASEAN+3 FTA versus Japan's proposal for a Comprehensive Economic Partnership Agreement to be pursued within the EAS. As Hughes points out, 29 Japan has been using regional institutions to counter China's rising influence, by deflecting Beijing's bids for dominance and "deliberately 'over-supplying' regionalism so as to diffuse China's ability to concentrate its power in any one forum." More recently, in assiduously courting ASEAN support for Japanese opposition to China's maritime assertiveness in 2013, the Abe Shinzo government again took the opportunity to increase the political momentum for the EAS as opposed to ASEAN+3. This regional habit of institutionracing has become even more widespread and mutually-reinforcing: ASEAN has responded to the economic arm of the US "rebalance" to Asia, the ambitious TPP trade liberalization negotiations, by starting talks on an RCEP trade pact with China, Japan, South Korea, India, Australia, and New Zealand. In so doing, the association appears to be reinforcing the pattern of countering regionalist enterprises that include the United States and non- 
Asian states by promoting exclusive regionalism that includes China at America's expense.

\section{The Great Power Bargain Deficit}

The above limitations of ASEAN-led multilateral institutions are related to ASEAN's imperative of maintaining its "relevance" in the rapidly changing Asia-Pacific strategic landscape. The fear of being sidelined in regional affairs on the basis of capacity leads the ASEAN states to prefer to help perpetuate some distance among the great powers, so that the latter would find it difficult to conduct independent dialogue or create a concert, and would rely instead on ASEAN's supposed brokerage. ${ }^{30}$ But these complex Southeast Asian strategies may not be innovative enough because they pay insufficient attention to two vital and related issues: the great power balance and the great power bargain.

In the process of enmeshing the regional great powers into multiple multilateral dialogues and mechanisms of cooperation, ASEAN has facilitated both continued US preponderance and China's integration in the region. The other East Asian states are now faced with some awkward questions about the balance of power-or more accurately, the deliberate imbalance of power, between the United States and other regional great powers. In particular, Southeast Asian states now need to consider how to persuade China to accept unequal power and authority vis-a-vis the United States. Southeast Asian strategists may have focused on constraining rising China at the expense of the even more difficult task of how to ensure that the United States tempers its preponderance with restraint and legitimacy. Most challenging of all, it is unclear how ASEAN multilateralism has helped to socialize US policymakers into the recognition that they must negotiate seriously with China over which elements of their mutual "core interests" are 
reasonable and legitimate, how these might be protected, and how they might identify and cooperate to achieve their shared imperatives in East Asia.

The other aspect of great power balance is the stuff of classic geopolitics: how should the changes in the US-Japan-China strategic triangle be managed? In material, operational, and legal terms, the American resurgence in East Asia has been crucially underpinned by updating and reinvigorating the US alliance with Japan. However, Japan's increased military capabilities and strategic role within the alliance since the mid-1990s has undermined China's assurance that the alliance keeps Japan in check, thus intensifying the trilateral security dilemma. .11 Southeast Asian states have very limited ability directly to transform the nature of this vital triangular relationship; what is required is a new set of strategic bargains that these great powers have to strike among themselves.

The optimistic view is that ASEAN has created overlapping institutions, which help to mute the security dilemma by offering great powers multiple opportunities to cooperate with different groups of states without generating zero-sum games. ${ }^{32}$ But the more profound task of creating regional order requires great power relations to be regulated in terms of institutionalized mutual understandings about constraints, rules of conduct, and conflict management. The urgent need for these "rules of the road" has been repeatedly highlighted by events in 2013: the flaring up of China and Japan's conflicting claims to the Senkaku/Diaoyu islands, China's controversial declaration of an air defense identification zone over the East China Sea and new fishing regulations in the South China Sea, and the near-collision of the USS Cowpens with a vessel accompanying the Chinese aircraft carrier Liaoning in the South China Sea. Yet, the Southeast Asian claim to mediating great power peace rests on not taking sides and in facilitating dialogue. In spite of constructivist arguments that this would in time shift state interests 
and create mutual identification, the ASEAN-centered channels do not yet appear to have helped substantively in negotiating mutual constraints and a modus vivendi among the great powers.

1. Hedley Bull, The Anarchical Society: A Study of Order in World Politics, 3rd ed. (Basingstoke: Palgrave, 2002); Muthiah Alagappa, ed., Asian Security Order: Instrumental and Normative Features (Stanford, CA: Stanford University Press, 2003).

2. Andrew Hurrell, On Global Order: Power, Values, and the Constitution of International Society (Oxford: Oxford University Press, 2007).

3. Andrew Hurrell, On Global Order, 31-32.

4. Lisa Martin, "The Rational State Choice of Multilateralism," in Multilateralism Matters: The Theory and Praxis of an Institutional Form, ed. John Gerald Ruggie, (New York: Columbia University Press, 1993), 91-124.

5. G. John Ikenberry, After Victory: Institutions, Strategic Restraint, and the Rebuilding of International Order after Major Wars (Princeton, NJ: Princeton University Press, 2001).

6. Evelyn Goh, The Struggle for Order: Hegemony, Resistance, and Transition in Post-Cold War East Asia (Oxford: Oxford University Press, 2013), Ch. 2.

7. Amitav Acharya, "Regional Institutions and Security in the Asia-Pacific," in Reassessing Security Cooperation in the Asia-Pacific: Competition, Congruence, and Transformation, ed. Amitav Acharya and Evelyn Goh (Cambridge: The MIT Press, 2007), 20-40. 
8. Alice Ba, "China and ASEAN: Re-navigating Relations for a 21 st Century Asia," Asian Survey 43, no. 4 (2003): 630-638.

9. Jose Almonte, "Ensuring the "ASEAN Way," Survival 39, no. 4 (1997/98): 80-92.

10. Alastair Iain Johnston, Social States: China in International Institutions, 1980-2000 (Princeton: Princeton University Press, 2008), 123.

11. Amitav Acharya and Evelyn Goh, eds. Reassessing Security Cooperation in the Asia-Pacific; Mely Caballero-Anthony, Ralf Emmers, and Amitav Acharya, eds., Non-Traditional Security in Asia: Dilemmas in Securitization (London: Ashgate, 2006).

12. Evelyn Goh, "The ASEAN Regional Forum in United States East Asian Strategy," The Pacific Review 17, no. 1 (2004): 47-69; William J. Clinton, "Fundamentals of Security for A New Pacific Century. Address before the National Assembly of the Republic of Korea, Seoul,” July 10, 1993.

13. Natasha Hamilton-Hart, Hard Interests, Soft Illusions: Southeast Asia and American Power (Ithaca: Cornell University Press 2012).

14. Goh Chok Tong, "Keynote address to the US-ASEAN Business Council annual dinner, Washington DC," Reprinted in The Straits Times, June 15, 2001.

15. Paul Midford, "Japan's Leadership Role in East Asian Security Multilateralism: The Nakayama Proposal and the Logic of Reassurance," Pacific Review 13, no. 3 (2000): 367-397; Soeya Yoshihide, “The Evolution 
of Japanese Thinking and Polices on Cooperative Security in the 1980s and 1990s," Australian Journal of International Affairs 48, no. 1 (1994): 87-95.

16. Michael Swaine and Ashley Tellis, Interpreting China's Grand Strategy (Santa Monica: RAND, 2000).

17. Rosemary Foot, "China in the ASEAN Regional Forum: Organizational Processes and Domestic Modes of Thought," Asian Survey 38, no. 5 (1998): 425-440; Alastair Iain Johnston, Social States.

18. Zheng Bijian, "China's 'Peaceful Rise' to Great Power Status," Foreign Affairs 84, no. 5 (2005): 18-24; Yong Deng, "Reputation and the Security Dilemma: China Reacts to the China Threat Theory," in New Directions in the Study of China's Foreign Policy, ed. Alastair Iain Johnston and Robert S. Ross (Stanford: Stanford University Press, 2006), 186-214.

19. Evelyn Goh, "Southeast Asian Perspectives on the China Challenge," Journal of Strategic Studies 30, no. 4 (2007): 809-832; David Shambaugh, "China Engages Asia: Reshaping the Regional Order," International Security 29, no. 3 (2004/05): 64-99.

20. ASEAN+3, created in 1997, is the most established East Asian economic cooperation institution, which has spawned a number of free trade agreements and more significantly, regional financial cooperation mechanisms such as the Chiang Mai Initiative regional currency swap facilities. The EAS is an annual meeting of the ASEAN+3 plus India, Australia, and New Zealand begun in 2005, and expanded to include the United States and Russia in 2011, which also addresses political and security issues but in smaller groupings than the ARF. The ADMM was inaugurated 
in 2006 and expanded in 2010 to include all EAS members (ADMM+). From 2011 the ADMM+ included the United States and Russia.

21. Sarah Eaton and Richard Stubbs, "Is ASEAN Powerful? Neo-realist versus Constructivist Approaches to Power in Southeast Asia," Pacific Review 19, no. 2 (2006): 135-155.

22. Donald Emmerson, "Asian Regionalism and US Policy: The Case for Creative Adaptation," RSIS Working Paper, no. 193 (March 2010).

23. Yuen Foong Khong, "Making Bricks without Straw in the Asia-Pacific?" Pacific Review 10, no. 2 (1997): 289-300.

24. Amitav Acharya and Evelyn Goh, eds., Reassessing Security Cooperation in the Asia-Pacific.

25. Goh, "The ASEAN Regional Forum."

26. Alica Ba, "China and ASEAN: Re-navigating Relations for a 21st Century Asia," Asian Survey 43, no. 4 (2003): 630-638.

27. Tanaka Akihiko, "The Development of the ASEAN+3 Framework," in Advancing East Asian Regionalism, ed. Melissa Curley and Nick Thomas (London: Routledge, 2006), 52-73.

28. Amitav Acharya and Evelyn Goh, eds., Reassessing Security Cooperation in the Asia-Pacific, 7. 
29. Christopher W. Hughes, “Japan's Response to China's Rise: Regional Engagement, Global Containment, Dangers of Collision," International Affairs 85, no. 4 (2009), 855.

30. Evelyn Goh, "Institutions and the Great Power Bargain in East Asia: ASEAN's Limited 'Brokerage' Role," International Relations of the AsiaPacific 11, no. 3 (2011): 373-401.

31. Evelyn Goh, "How Japan Matters in the Evolving East Asian Security Order," International Affairs 87, no. 4 (2011): 887-902.

32. Victor Cha, "Complex Patchworks: US Alliances as Part of Asia's Regional Architecture," Asia Policy 11 (2011): 27-50. 